Jurnal Ilmiah "Kreatif" Vol. 18 No. 2, Juli 2020

"Jurnal Studi Pemikiran Pendidikan Agama Islam"

\title{
KREATIVITAS GURU SD/MI DALAM MENDESAIN \\ PEMBELAJARAN PAI DAN IMPLIKASINYA TERHADAP PENANAMAN SIKAP TOLERANSI SISWA DI MIN 1 SILA
}

\author{
Syahru Ramadhan \\ Institut Agama Islam (IAI) Muhammadiyah Bima \\ Email: syahrupgmi05@gmail.com
}

\begin{abstract}
Abstrak
Artikel ini akan menjelaskan tentang persoalan yang tengah dihadapi oleh bangsa ini adalah minimnya rasa untuk saling menghargai dan sikap terbuka dalam menerima setiap perbedaan baik dalam konteks hubungan sosial, hak asai manusia dan kehidupan beragama. Sehingga guru perlu mendesain sebuah kegiatan pembelajaran yang berorientasi pada penanaman sikap toleransi. Penelitian ini bertujuan untuk mendiskripsikan secara umum tentang kreativitas guru SD/MI dalam mendesain pembelajaran PAI dan implikasinya terhadap pengembangan sikap toleransi siswa di MIN 1 Sila. Penelitian ini menggunakan pendekatan kualitatif dengan jenis penelitian studi kasus. Metode pengumpulan data dengan wawancara, observasi, dan dokumentasi. Adapun sumber informan dalam penelitian ini adalah kepala sekolah, Wakasek Kurikulum dan guru mata pelajaran PAI. Adapun metode pengumpulan data dalam penelitian adalah melalui observasi, wawancara dan dokumentasi. Metode analisis data menggunakan teknik analisis deskriptif. Adapun hasil penelitiannya adalah Dalam pembelajaran PAI, penanaman sikap toleransi adalah salah satu aspek yang sangat ditekankan. Ajaran islam yang dipelajari pada mata pelajaran pendidikan agama islam tidak hanya dipahami secara tekstual normatif, dalam artian doktrin-doktrin yang diajarakan dalam Al-Qur'an harus mampu dipahami secara terbuka dan tidak diskriminatif. Proses perencanaan, pelaksanaan, dan evaluasi pada mata pelajaran PAI harus berorientasi pada pengembangan keterampilan pengetahuan, sikap dan keterampilan. Sehingga sikap toleransi bukanlah sesuatu yang hadir secara spontanitas, tetapi merupakan desain guru PAI dalam pembelajaran.
\end{abstract}

Kata Kunci: Kreativitas Guru, Pembelajaran PAI, Toleransi

\section{Pendahuluan}

Pertumbuhan dan perkembangan siswa sifatnya sangatlah kompleks, baik secara fisik maupun psikis. Fenomena ini juga terlihat dalam penerapan pembelajaran PAI yang mengharuskan siswa untuk terus terlibat secara aktif dalam proses pembelajaran. Dalam mengoptimalkan proses pertumbuhan 
Jurnal Ilmiah "Kreatif" Vol. 18 No. 2, Juli 2020

"Jurnal Studi Pemikiran Pendidikan Agama Islam"

dan perkembangan siswa, maka kreativitas guru sangat menentukan tingkat keberhasilannya. Secara rinci dalam pasal 3 UU N0. 2 tahun 2003 tentang Sistem Pendidikan Nasional (SISDIKNAS) disebutkan bahwa : "Pendidikan nasional berfungsi mengembangkan kemampuan dan membentuk watak serta peradaban bangsa yang bermanfaat dalam rangka mencerdaskan kehidupan bangsa, bertujuan untuk berkembangnya peserta didik agar menjadi manusia yang beriman dan bertaqwa kepada Tuhan Yang Maha Esa, berakhlak mulia, sehat, berilmu, cakap, kreatif, mandiri dan menjadi warga Negara yang demokratis serta bertanggung jawab". Untuk mencapai pendidikan nasional diperlukan adanya pendidikan dan proses pembelajaran yang efektif dan efisien. ${ }^{1}$

Seorang guru yang kreatif akan memiliki sikap kepekaan, inisiatif, cara baru dalam mengajar, kepemimpinan serta tanggungjawab yang tinggi dalam pekerjaan dan tugasnya sebagai seorang pendidik. Guru kreatif adalah salah satu faktor yang mempengaruhi kualitas pendidikan. Kualitas pembelajaran dipengaruhi pula oleh sikap guru yang kreatif untuk memilih dan melaksanakan pendekatan dan model pembelajaran. Karena profesi guru menuntut sifat kreatif dan kemauan mengadakan improvisasi. Oleh karena itu guru harus menumbuhkan dan mengembangkan sifat kreatifnya. Kreativitas guru dapat diciptakan dan dikembangkan apabila dipupuk sejak dini, dan seorang guru menyadari betul manfaat dari kreativitas tersebut. ${ }^{2}$

Dalam penelitian yang dilakukan oleh Balitbang dan Diklat Kemenag pada tahun 2009 di sepuluh kota di sepuluh propinsi di Indonesia, peran Kelompok Kerja Guru Agama Islam (KKGAI) dalam peningkatan profesionalisme guru PAI di SD/MI masih kurang, bahkan hanya satu indikator yang berkategori cukup. Hal itu dapat diketahui dari beberapa indikator sebagai berikut: pertama, peran KKG dalam mencapai tujuannya, kedua, peran KKG dalam menjalankan tugas dan tanggung jawab, ketiga, peran KKG dalam menjalankan mekanisme kerja, dan keempat, peran KKG dalam menjalankan kegiatan, sedangkan untuk indikator peran KKG dalam

\footnotetext{
${ }^{1}$ Depdiknas, UU No. 2 Tentang Sistem Pendidikan Nasional (SISDIKNAS), (Jakarta: Depdiknas 2003).

${ }^{2}$ Siti Aesijah dan Eko Raharjo, Kreativitas Guru Dalam Pembelajaran Musik Di Taman Kanak-Kanak (TK) Kemala Bhayangakari 62 Boyolali. Dalam Jurnal Seni Musik No. 6 Vol. 2 Universitas Negeri Semarang, 2017, hlm. 61.
} 
Jurnal Ilmiah "Kreatif" Vol. 18 No. 2, Juli 2020

"Jurnal Studi Pemikiran Pendidikan Agama Islam"

proses evaluasi dan pelaporan hanya berkategori cukup. Dengan kata lain, peran KKGAI masih belum sesuai dengan harapan. ${ }^{3}$

Secara konseptual Pendidikan Agama Islam (PAI) menempati posisi yang sangat penting dalam membentuk, mewarnai dan mendukung tujuan pembangunan nasioanl, khususnya aspek pembangunan karakter dan spirit sumber daya manusia Indonesia yang memiliki watak kebangsaan dan pembangunan. ${ }^{4}$ Pada tataran yang lebih substansial, pendidikan agama islam juga diharapkan dapat menjadi sarana pendidikan untuk meningkatkan keimanan, dan akhlak mulia yang tercermin dalam ketaatan beribadah disertai dengan menumbuhkan sikap mendukung toleransi, kerukunan antar kelompok umat beragama serta pendidikan berwawasan kebangsaan bagi masyarakat Indonesia. ${ }^{5}$ Marwan Sarijo menyebutkan bahwa hanya bagi mereka yang memahami agamanya dengan benar yang dapat menghargai keyakinan seseorang yang berlainan agama. ${ }^{6}$ Dengan begitu, kehadiran orang tersebut dimanapun ia berada selalu berusaha menampakan wajah Islam yang "rahmatan lil alamin" bagi kehidupan bangsa Indonesia.

Disisi lain Muchtar Buchari menilai, kegagalan pelaksanaan pendidikan agama islam disebabkan karena praktek pendidikannya hanya memperhatikan aspek kognitif semata daripada pertumbuhan kesadaran nilai-nilai (agama), dan mengabaikan pembinaan aspek afektif dan konatifvolutif, yakni kemauan dan tekad untuk mengamalkan nilai-nilai ajaran Islam. ${ }^{8}$ Problematika tersebut juga diungkapkan pakar Islam nonpendidikan oleh M. Amin Abdullah yakni pendidikan agama islam lebih banyak terkonsentrasi pada persoalan-persoalan teoritis keagamaan yang bersifat kognitif semata, serta amalan-amalan ibadah praktis. Sehingga menurut

\footnotetext{
${ }^{3}$ Amen Haedari, Sinopsis Kajian Pendidikan Agama dan Keagamaan 2006-2009 (Jakarta: Puslitbang Pendidikan Agama dan Keagamaan Badang Litbang dan Diklat Kementrian Agama RI, 2010), hlm. 91.

${ }^{4}$ Marwan Saridjo, Bunga Rampai Pendidikan Agama Islam (Jakarta: Amisso, 1996), hlm. 64

${ }^{5}$ Imam Tholkhah, Urgensi Pengembangan Pengembangan Pendidikan Agama Islam di Sekolah (Jakarta: Rajagrafindo Persada, 2009), hlm. 114.

${ }^{6}$ Marwan Saridjo, Bunga Rampai Pendidikan ......, hlm. 51

${ }^{7}$ Marwan Saridjo, Pendidikan Islam Dari Masa ke Mas: Tinjauan Kebijakan Publik Terhadap Pendidikan Islam di Indonesia (Bogor: Ngali Aksara dan Al-Manar Press, 2011), hlm. 168.

${ }^{8}$ Muhaimin, dkk., Paradigma Pendidikan Islam: Upaya Mengefektifkan Pendidikan Agama Islam di Sekolah (Bandung: Remaja Rosdakarya, 2004), hlm. 89.
} 
Jurnal Ilmiah "Kreatif" Vol. 18 No. 2, Juli 2020 "Jurnal Studi Pemikiran Pendidikan Agama Islam"

beliau guru harus mampu mengubah pengetahuan agama yang kognitif tadi menjadi bermakna dan bernilai yang diinternalisasikan dalam diri siswa lewat berbagai cara, media dan forum. ${ }^{9}$ Lebih lanjut Komarudin Hidayat menyarankan agar perlunya menonjolkan dua pendekatan sekaligus dalam mempelajari Islam, yaitu mempelajari Islam untuk kepentingan dalam mengetahui bagaimana cara Bergama yang benar, dan mempelajari Islam sebagai sebuah pengetahuan. ${ }^{10}$ Oleh karena itu, mepelajari Islam adalah untuk membentuk perilaku yang memiliki komitmen, loyal dan penuh dedikasi dan sekaligus mampu memosisikan diri sebagai pembelajar, peneliti, dan pengamat yang kritis untuk peningkatan dan pengembangan keilmuan Islam.

Persoalan lain yang terjadi ditengah kemajemukan masyarakat Indonesia adalah minimnya rasa untuk saling menghargai dan sikap terbuka dalam menerima setiap perbedaan baik dalam konteks hubungan sosial, hak asai manusia dan kehidupan beragama. Sehingga guru perlu mendesain sebuah kegiatan pembelajaran yang berorientasi pada penanaman sikap toleransi. Syafiq A. Mughni menjelaskan bahwa toleransi adalah sikap menerima bahwa orang lain berbeda dengan kita. Toleransi diperlukan tidak hanya pada tataran konseptual, melainkan juga pada tingkat teknis operasional. ${ }^{11}$ Sistem pendidikan kita selama ini terlalu menitip beratkan pada pengayaan pengetahuan dan keterampilan tetapi mengabaikan perhargaan atas nilai-nilai agama, budaya dan tradisi bangsa ini. ${ }^{12}$ Maka kehadiran konsep desain pembelajaran PAI yang menghargai dan menjunjung tinggi terwujdnya kesetaraan hubungan merupakan suatu keniscayaan bagi dunia pendidikan nasional kita saat ini.

Madrasah Ibtidaiyah Negeri (MIN) 1 Sila merupakan salah satu lembaga pendidikan yang merespon positif terhadap kebijakan pendidikan yang mengarahkan kegiatan pembelajaran pada mata pelajaran agama islam dengan penanaman nilai sikap toleransi melalui Kurikulum 2013 yang menjadi pedoman penyelenggaraan pendidikan saat ini. Meski secara legal

\footnotetext{
${ }^{9}$ Ibid., hlm. 90.

${ }^{10}$ Ibid., hlm. 91.

${ }^{11}$ Syafiq A. Mughni, Pendidikan Berbasis Multikulturalisme (Sidorjo: Universitas Muhammadiyah Sidoarjo, 2005), hlm. 14.

${ }^{12}$ Choirul Mahfud, Pendidikan Multikultural (Yogyakarta: Pustaka Pelajar, 2014), hlm. 14.
} 
Jurnal Ilmiah "Kreatif" Vol. 18 No. 2, Juli 2020

"Jurnal Studi Pemikiran Pendidikan Agama Islam"

formal MIN 1 Sila tidak menobatkan diri sebagai sekolah berbasis toleransi dalam beragama, tetapi telah membuktikan adanya konsep dan implementasi pembelajaran PAI berbasis toleransi melalui aktivitas dan kegiatan madrasah yang berupaya untuk mendidikan nilai-nilai ajaran Islam ke dalam kegiatan pembelajaran.

Untuk memecahkan problematika pembelajaran pendidikan agama Islam di sekolah atau madrasah tersebut, solusi yang ditawarkan oleh penulis melalui peneltian ini adalah guru perlu mengembangkan pembelajaran PAI di MIN 1 Sila yaitu menggunakan model pembelajaran konstruktivistik. Karena kecendrungan anak usia SD/MI memiliki tiga ciri, yaitu: konkrit, integratif dan kontekstual. Oleh karena demikian penulis berpandangan bahwa kreativitas guru SD/MI dalam mendesain pembelajaran PAI dan implikasinya terhadap keterampilan sikap toleransi siswa di MIN 1 Sila sangat penting untuk dilakukan proses penelitian secara ilmiah, agar kedepan guru dapat mengformulasikan sebuah kegiatan pembelajan PAI yang kontekstual.

\section{Tinjauan Teoritis \\ Kreativitas Guru}

Guru merupakan jabatan atau profesi yang memerlukan keahlian khusus sebagai guru. Pekerjaan ini, tidak bisa dilakukan oleh orang yang tidak memiliki keahlian untuk melakukan kegiatan atau pekerjaan sebagai guru. Guru adalah pendidik professional dengan tugas utama mendidik, mengajar, membimbing, mengarahkan, melatih, menilai, dan mengevaluasi peserta didik pada pendidikan anak usia dini jalur pendidikan formal, pendidikan dasar, dan pendidikan menengah. Seorang guru memang harus dituntut untuk menjadi kreatif, profesional dan menyenangkan. ${ }^{13}$ Kreativitas dalam pembelajaran sangat penting artinya untuk menumbuhkembangkan potensi yang dimiliki oleh anak didik. Kreativitas diantara cirinya adalah sebagai sesuatu yang langka yang tidak semua orang mampu melakukannya. Kreativitas memang bukan merupakan sesuatu yang mudah

\footnotetext{
${ }^{13}$ Moch. Uzer Usman, Menjadi Guru Profesional, (Bandung: PT Remaja Rosdakarya,2011), hlm.5.
} 
Jurnal Ilmiah "Kreatif" Vol. 18 No. 2, Juli 2020

"Jurnal Studi Pemikiran Pendidikan Agama Islam"

untuk dilakukan. Namun kreativitas harus diusahakan dan diciptakan secara terus menerus. $^{14}$

Kreativitas Guru adalah salah satu faktor yang mempengaruhi kualitas pendidikan. Para pakar menyatakan bahwa betapapun bagusnya sebuah kurikulum (official), hasilnya sangat tergantung pada apapun yang dilakukan guru di dalam atau di luar kelas (actual). ${ }^{15}$ Kualitas pembelajaran dipengaruhi pula oleh sikap guru yang kreatif untuk memilih dan melaksanakan pendekatan dan model pembelajaran. Karena profesi guru menuntut sifat kreatif dan kemauan mengadakan improvisasi. ${ }^{16}$ Oleh karena itu, guru harus mengembangkan kreativitasnya dalam proses pembelajaran. Kreativitas guru dapat diciptakan dan dikembangkan apabila dipupuk sejak dini, dan seorang guru menyadari betul manfaat dari kreativitas tersebut.

Ciri-ciri atau karakteristik guru kreatif, sebagaimana dikemukakan Mark Sund, adalah sebagai berikut:

1. Guru kreatif memiliki rasa ingin tahu yang sangat besar, sehingga mendorong seorang guru untuk mengetahui hal-hal baru yang berkaitan dengan aktivitas dan pekerjaannya sebagai guru.

2. Guru kreatif memiliki sikap yang ekstrovert atau bersikap lebih terbuka dalam menerima hal-hal baru dan selalu ingin mencoba untuk melakukannya, dan dapat menerima masukan dan saran dari siapapun yang berkaitan dengan pekerjaannya, dan menganggap bahwa hal-hal baru tersebut dapat menjadi pengalaman dan pelajaran baru bagi dirinya.

3. Guru kreatif biasanya tidak kehilangan akal dalam menghadapi masalah tertentu, sehingga sangat kreatif dan "panjang akal" untuk menemukan solusi dari setiap masalah yang muncul. Dan bahkan lebih cenderung menyukai tugas yang berat dan sulit karena akan menimbulkan rasa kepuasan tersendiri setelah mampu menyelesaikan tugas tersebut.

\footnotetext{
${ }^{14}$ Ngainun Naim, Menjadi Guru Inspiratif Memberdayakan dan Mengubah Jalan Hidup Siswa, (Yogyakarta: Pustaka Pelajar, 2009), hlm. 139.

${ }^{15}$ Nana Syaodih Sukmadinata, Pengembangan Kurikulum, (Bandung: Remaja Rosdakarya: 1995), hlm.194.

${ }^{16}$ Ibid., hlm. 115
} 
Jurnal Ilmiah "Kreatif" Vol. 18 No. 2, Juli 2020

"Jurnal Studi Pemikiran Pendidikan Agama Islam"

4. Guru kreatif sangat termotivasi untuk menemukan hal-hal baru baik melalui observasi, pengalaman dan pengamatan langsung dan melalui kegiatan-kegiatan penelitian. Hal ini disebabkan karena guru kreatif cenderung mencari jawaban yang luas dan memuaskan secara ilmiah. ${ }^{17}$

\section{Desain Pembelajaran PAI}

\section{Pengertian Pendidikan Agama IsIma di SD/MI}

Pendidikan agama Islam adalah sebutan yang diberikan pada salah satu mata pelajaran yang harus dipelajari oleh siswa Muslim (orang beragama Islam) dalam menyelesaikan pendidikannya pada tingkat tertentu. Ia merupakan bagian yang tak terpisahakn dari kurikulum suatu sekolah atau madrasah sehingga merupakan alat untuk mencapai salah satu aspek tujuan sekolah yang bersangkutan. Dengan demikian, pendidikan agama Islam dapat dicapai dengan memberikan materi atau pengalaman yang berisi ajaran agama Islam, yang biasanya telah tersusun secara sistematis dalam ilmu-ilmu keislaman. ${ }^{18}$

Pandangan lain tentang pendidikan agama Islam dikemukakan oleh Abdul Rachman shaleh, ia mengatakan bahwa pendidikan Islam merupakan usaha sadar untuk mengarahkan pertumbuhan dan perkembangan anak dengan segala potensi yang dianugerahkan oleh Allah kepadanya agar mampu mengemban amanah dan tanggung jawab sebagai khalifah Allah di bumi dan pengabdiannya kepada Allah. ${ }^{19}$ Karena itu, keberadaan mata pelajaran ini diharapkan dapat memberikan keseimbangan dalam kehidupan anak kelak yaitu ilmu umum dan ilmu agama, sehingga mampu membentuk manusia yang utuh. Hal senada Zuhairini, pendidikan agama Islam adalah usaha berupa bimbingan kea

\footnotetext{
${ }^{17}$ Guntur Talajan, Menumbuhkan Kreativitas dan Prestasi Guru (Yogyakarta: Laksbang Pressindo, 2012), hlm. 34-35.

${ }^{18}$ Ibnu Hadjar, Pendekatan Keberagamaan Dalam Pemilihan Metode Pengajaran Pendidikan Agama Islam (Yogyakarta: Pustaka Pelajar, 2004), hlm. 4.

${ }^{19}$ Abdul Rachman Shaleh, Pendidikan Agama dan Keagamaan: Visi, Misi dan Aksi (Jakarta: Gemawindu Pancaperkasa, 2000), hlm. 2.
} 
Jurnal Ilmiah "Kreatif" Vol. 18 No. 2, Juli 2020 "Jurnal Studi Pemikiran Pendidikan Agama Islam"

rah pertumbuhan kepribadian siswa secara sistematis dan pragmatis supaya mereka hidup sesuai dengan ajaran Islam, sehingga terjalin kebahagiaan hidup dunia dan akhirat. ${ }^{20}$

Dari beberapa pengertian diatas, maka pendidikan agama Islam mangandung beberapa unsur diantaranya pendidikan agama Islam di $\mathrm{SD} / \mathrm{MI}$ dilaksanakan sebagai sebuah kegiatan yang terencana. Guru juga menyadari betul setiap tindakan yang ia lakukan akan menimbulkan berbagai dampak bagi siswa. Oleh karena itu, pendidikan agama Islam di SD/MI dilakukan dengan pertimbangan yang masak, baik pada aspek perkembangan siswa meliputi perkembangan fisik, psikis, kognisi, social, dan religiulitas, maupun pada aspek materi yang disampikan. PAI di SD/MI juga tidak boleh dilakukan secara serampangan dan tanpa perencanaan, karena hal itu akan berakibat fatal bagi siswa. Maka segala tindakan edukatif yang dilakukan oleh guru PAI sesungguihnya merupakan sebuah intervensi, atau suatu rangsangan eksternal (perlakukan) yang diberikan oleh guru sehingga siswa dapat belajar agama Islam. $^{21}$

Melalui proses bimbingan dan pengarahan, pendidikan agama Islam disatu sisi adalah memosisikan siswa sebagai subyek yang aktif, tetapi disisi yang lain guru memosisikan diri sebagai pihak yang lebih berpengetahuan dibandingkan siswa, maka ada dua hal yang dilakukan dalam pendidikan agama Islam di SD/MI, yaitu membimbing dan mengarahkan. ${ }^{22}$ Membimbing adalah suatu kegiatan mendampingi siswa agar kemandirian mereka untuk belajar muncul, sehingga mereka mampu mengontruksi sendiri pengetahuannya sekaligus menginternalisasi nilainilai Islam dalam karakter dan kepribadiannya. Sedangkan mengarahkan adalah guru sebagai pribadi yang dianggap lebih dewasa dan lebih

\footnotetext{
${ }^{20}$ Ahmad Munjin dan Lilik Nur Kholidah, Metode dan Tekhnik Pembelajaran Pendidikan Agama Islam (Bandung: Rafida Aditama, 2009), hlm. 5.

${ }^{21}$ Andi Prastowo, Pembelajaran Konstruktivistik-Saintific Untuk Pendidikan Agama di Sekolah/Madrasah (Jakarta: Raja Grafindo Persada, 2015), hlm. 39.

${ }^{22}$ Ibid., hlm 40.
} 
Jurnal Ilmiah "Kreatif" Vol. 18 No. 2, Juli 2020

"Jurnal Studi Pemikiran Pendidikan Agama Islam"

berkompeten dibandingkan siswa, pada suatu saat (tetapi bukan mendominasi) tertentu harus menjelaskan dan melatih secara langsung siswa. Sehingga mereka mampu menguasai kompetensi yang diharapkan secara baik.

\section{Fungsi dan Tujuan PAI di SD/MI}

Sebagai suatu mata pelajaran, Pendidikan Agama Islam memiliki fungsi yang berbeda dibandingkan mata pelajaran yang lain. Secara umum Ibnu Hajar menjelaskan fungsi pendidikan agama islam di SD/MI sebagai berikut:

a. Fungsi Konvensional, pendidikan agama islam ditujukan untuk meningkatkan komitmen dan perilaku keberagamaan siswa.

b. Fungsi Neo Konvensional, pendidikan agama islam dimaksudkan untuk meningkatkan keberagamaan siswa sesuai dengan keyakinannya.

c. Fungsi Konvensional Tersembunyi, pendidikan agama islam menawarkan sejumlah pilihan ajaran agama dengan harapan siswa nantinya akan memilih salah satu yang dianggap paling benar dan sesuai dengan dirinya.

d. Fungsi Imlisit, untuk mengenalkan kepada siswa ajaran Islam secara terpadu dengan seluruh aspek kehidupan melalui berbagai mata pelajaran.

e. Fungsi Non-Konvensional, pendidikan agama islam dimaksudkan sebagai alat untuk memahami keyakinan atau pandangan hidup yang dianut oleh orang lain. ${ }^{23}$

Jika melihat fungsi-fungsi yang telah dijelaskan diatas, pendidikan agama Islam sebagai salah satu pendidikan agama di Indonesia diharapkan dapat mengantarkan siswa memiliki karakteristik sosok manusia Muslim yang diidealkan sekaligus memiliki sikap toleransi yang tinggi terhadap pemeluk agama lain.

\footnotetext{
${ }^{23}$ Ibnu Hadjar, Pendekatan Keberagamaan ....., hlm. 12.
} 
Jurnal Ilmiah "Kreatif" Vol. 18 No. 2, Juli 2020

"Jurnal Studi Pemikiran Pendidikan Agama Islam"

Sementara itu, Pendidikan Agama Islam sebagai suatu disiplin ilmu nmempunyai karakteristik dan tujuan yang berbeda dari disiplin ilmu yang lain. Secara umum menurut Nizar, pendidikan agama Islam mempunyai tujuan yang dapat diklasifikasikan menjadi tiga kelompok, yaitu pertama, Tujuan jismiyah berorientasi pada tugas manusia sebagai khalifah fi al-ardh, kedua, Tujuan Ruhiyyat berorientasi pada kemampuan manusia dalam menerima ajaran Islam secara kaffah sebagai hamba Allah, ketiga, Tujuan Aqliyyat berorientasi pada pengembangan intelligence otak siswa. $^{24}$

Menurut Pusat Kurikulum Depdiknas, pendidikan agama Islam di Indonesia bertujuan untuk menumbuhkan dan meningkatkan keimanan siswa melalui pemberian dan pemupukan pengetahuan, penghayatan, pengamalan serta pengalaman siswa tentang agama Islam sehingga menjadi manusia Muslim yang terus berkembang dalam hal keimanan, ketakwaannya kepada Allah SWT, serta berakhlak mulia dalam kehidupan pribadi, bermasyarakat, berbangsa dan bernegara. ${ }^{25}$

\section{Ruang Lingkup Materi PAI di SD/MI}

Menurut Nasih dan Khalidah, pendidikan agama Islam di sekolah maupun madrasah memiliki aspek-aspek yang sama. Ada tiga aspek dalam pendidikan agama Islam yaitu: pertama, aspek hubungan manusia dengan Allah SWT, kedua, aspek hubungan manusia dengan sesamanya, dan ketiga, hubungan manusia dengan alam. ${ }^{26}$

Sementara itu, dalam peraturan Menteri Agama RI No. 2Tahun 2008 tentang Standar Isi dan Standar Kompetensi Lulusan Pendidikan Agama Islam di madrasah diungkapkan bahwa pendidikan agama Islam di madrasah ibtidaiyah terdiri atas empat mata pelajaran, yaitu: Al-

\footnotetext{
${ }^{24}$ Ahmad Munjin Nasih dan Lilik Nur Kholidah, Metode dan Tekhnik pembelajaran ..., hlm. 8

${ }^{25}$ Pusat Kurikulum Depdiknas, Standar Kompetensi Mata Pelajaran Agama Islam Sekolah Dasar dan Madrasah Ibtidaiyah (Jakarta, Depdiknas, 2004), hlm. 4.

${ }^{26}$ Ahmad Munjin nasih dan Lilik Nur Kholidah, Metode dan Tekhnik Pembelajaran ..., hlm. 10 .
} 
Jurnal Ilmiah "Kreatif" Vol. 18 No. 2, Juli 2020 "Jurnal Studi Pemikiran Pendidikan Agama Islam"

Qur'an-Hadits, Akidah Akhlak, Fiqih dan Sejarah Kebudayaan Islam. Masiing-masing mata pelajaran tersebut pada dasarnya saling terkait, isi mengisi dan saling melengkapi.

Al-Qur'an dan Hadits merupakan sumber utama ajaran Islam, dalam arti ia merupakan sumber aqidah-akhlak, Syariah/Fiqih (Ibadah, muamalah), sehingga kajiannya berada disetiap unsur tersebut. Aqidah atau keimanan merupakan akar atau pokok agama. Syariah atau fiqih merupakan sistem norma yang mengatur hubungan manusia dengan Allah, sesama manusia dan makhluk lainnya. Akhlak merupakan aspek sikap hidup atau kepribadian hidup manusia, dalam berarti bagaimana sistem norma yang mengatur hubungan manusia dengan Allah.

Dari penjelasan tersebut dapat disimpulkan bahwa ruang lingkup PAI di SD/MI meliputi empat aspek, yaitu Al-Qur'an-Hadits, Aqidah Akhlak, Syariah atau Fiqih, dan Sejarah Kebudayaan Islam. Keempatempatnya relasinya saling mengisi dan melengkapi.

\section{Model Pembelajaran PAI di SD/MI}

Model pembelajaran pendidikan agama Islam untuk sekolah atau madrasah yakni menggunakan model pembelajaran tematik sesuai dengan kurikulum yang baru yakni kurikulum 2013. Trianto mengungkapkan bahwa model pembelajaran tematik adalah pembelajaran yang dirancang berdasarkan tema-tema tertentu. Dalam pembahasannya tema itu ditinjau dari berbagai mata pelajaran. ${ }^{27}$ Model pembelajaran tematik adalah model pembelajaran terpadu yang menggunakan pendekatan tematik yang melibatkan beberapa mata pelajaran untuk memberikan pengalaman bermakna kepada siswa. Disebut bermakna menurut Rusman, dikarenakan dalam pembelajaran tematik, siswa akan memahami konsep-konsep yang mereka pelajari

27 Trianto, Desain Pengembangan Pembelajaran Tematik Bagi Anak Usia Dini TK/RA dan Anak Usia Awal SD/MI (Jakarta: Kencana Prenada Media Group, 2013), hlm. 147. 
Jurnal Ilmiah "Kreatif" Vol. 18 No. 2, Juli 2020

"Jurnal Studi Pemikiran Pendidikan Agama Islam"

melalui pengalaman langsung dan menghubungkannya dengan konsep lain yang telah dipahaminya. ${ }^{28}$

Dalam praktiknya, pendekatan pembelajaran tematik inibertolak dari suatu temayang dipilih dan dikembangkan oleh guru bersama siswa dengan memperhatikan keterkaitannya dengan isi mata pelajaran. Tema adalah pokok pikiran atau gagasan pokok yang menjadi pokok pembicaraan. Tujuan dari adanya tema ini bukan hanya untuk menguasai konsep-konsep dalam suatu mata pelajaran, akan tetapi juga keterkaitannya dengan konsep-konsep dari mata pelajaran lainnya. ${ }^{29}$

Dengan demikian, dapat kita pahami bahwa model pembelajaran tematik pada dasarnya merupakan model pembelajaran yang menggunakan pendekatan tematik dengan menekankan keterlibatan siswa secara aktif dan menyenangkan, yakni tidak semata-mata mendorong peserta didik untuk mengetahui (learning to know), tetapi belajar juga untuk melakukan (learning to do), belajar untuk menjadi (learning to be), dan belajar untuk hidup bersama (learning to live together), sehingga aktivitas pembelajaran itu relevan dan penuh makna bagi siswa.

\section{Sikap Toleransi}

Toleransi berasal dari kata dasar "toleran" yang artinya bersifat dan bersikap menenggang (menghargai, membiarkan, membolehkan) pendirian (pendapat, pandangan, kepercayaan, kebiasaan, perilaku, dan sebagainya) yang berbeda atau bertentangan dengan pendirian sendiri. ${ }^{30}$ Sedangkan toleransi berarti sifat atau sikap toleran.Jadi toleransi dapat diartikan sebagai sikap menghargai pendirian yang berbeda dengan pendiriannya sendiri.Toleransi merupakan sikap pengakuan terhadapkemajemukan pandangan, kepercayaan yang berbeda demi menjunjungkehidupan bermasyarakat yang harmonis. Sedangkan toleransi dalam hidup beragama

\footnotetext{
${ }^{28}$ Rusman, Model-model Pembelajara: Mengembangkan Profesionalisme Guru (Jakarta: Rajawali Pers, 2010), hlm. 254.

${ }^{29}$ Tim Penyusun Pusat Bahasa Depdiknas, Kamus Besar Bahasa Indonesia, Edisi Keempat (Jakarta: Gramedia Pustaka Utama, 2008), hlm. 1429.

${ }^{30}$ Kamus Besar Bahasa Indonesia, (Jakarta: Balai Pustaka: 1997), hlm. 1066.
} 
Jurnal Ilmiah "Kreatif" Vol. 18 No. 2, Juli 2020 "Jurnal Studi Pemikiran Pendidikan Agama Islam"

merupakan kenyataan bahwa banyak orang yang memeluk agama yang berbeda-beda sehingga kita perlu mengakuinya sebagai saudara se-Tuhan. Makna kata toleransi lebih pada keterlibatan aktif sehingga setiap umat beragama diharapkan dapat berinteraksi secara positif dalam lingkungan majemuk. Umat beragama diharapkan bersedia menerima kenyataan pendapat yang berbeda-beda tentang kebenaran yang dianut, dapat menghargai keyakinan orang lain terhadap agama yang dipeluknya serta memberi kebebasan dalam menjalankan ajaran yang dianutnya dengan tidak bersikap mencela dan atau memusuhinya.

Menurut Nurholis Majid toleransi bukan sekedar persoalan prosedural- tata cara pergaulan untuk kerukunan hidup- antara berbagai kelompok yang berbeda. Akan tetapi toleransi merupakan masalah prinsip ajaran kebenaran dan kewajiban melakukannya. ${ }^{31}$

Dalam mengamalkan toleransi ada beberapa hal yang perlu dilaksanakan yaitu (1) Mengakui persamaan derajat, persamaan hak dan persamaan kewajiban antar sesama manusia; (2) Saling mencintai sesama manusia; (3) Mengembangkan sikap tenggang rasa; (4) Tidak semena-mena terhadap orang lain; (5) Menjunjung tinggi nilai kemanusiaan; (6) Gemar melakukan kegiatan kemanusiaan; (7) Berani membela kebenaran dan keadilan serta (8) Merasa sebagai bagian dari umat manusia. ${ }^{32}$

Sikap pluralis dan toleran semacam inilah yang seharusnya ditumbuh-kembangkan lewat berbagai macam institusi yang ada termasuk lewat jalur pendidikan. Berpedoman pada standar kompetensi lulusan dan standar isi serta panduan penyusunan kurikulum yang dikembangkan oleh Badan Standar Nasional Pendidikan (BSNP) yang dibentuk berdasarkan Peraturan Pemerintah Nomor 19 Tahun 2005. Kurikulum dikembangkan salah satunya dengan memperhatikan keragaman karakteristik peserta didik,

\footnotetext{
${ }^{31}$ Nurholish Madjid, Cendikiawan \& Religiusitas Masyarakat, (Jakarta :Paramadina, 1999), hlm. 66.

${ }^{32}$ Imron Rossidy, Pendidikan Berparadigma Inklusif, (Malang:UIN Malang Press, 2009), hlm.163.
} 
Jurnal Ilmiah "Kreatif" Vol. 18 No. 2, Juli 2020

"Jurnal Studi Pemikiran Pendidikan Agama Islam"

kondisi daerah, dan jenjang serta jenis pendidikan, tanpa membedakan agama, suku, budaya dan adat istiadat, serta status social ekonomi dan gender. Kurikulum tersebut dilaksanakan dengan menegakkan kelima pilar belajar, yaitu (a) belajar untuk beriman dan bertakwa kepada Tuhan Yang Maha Esa, (b) belajar untuk memahami dan menghayati, (c) belajar untuk mampu melaksanakan dan berbuat secara efektif, (d) belajar untuk hidup bersama dan berguna bagi orang lain, dan (e) belajar untuk membangun dan menemukan jati diri, melalui proses pembelajaran yang aktif, kreatif, efektif, dan menyenangkan. ${ }^{33}$

Oleh karena itu, untuk mengembangkan sikap toleran terhadap golongan lain dan kerukunan hidup beragama, maka perlu dikembangkan model pembelajaran alternatif. Para pendidik sebagai seorang fasilitator sekaligus sebagai pengarah untuk dapat mengarahkan peserta didiknya untuk menjadi seorang yang mempunyai sikap toleransi dan kerukunan yang tinggi sehingga dapat memahami dan menilai kehidupan yang beragam ini dengan bijaksana. Maka dari itu, salah satu model alternatif untuk mencapai hal itu, yaitu model pembelajaran pendidikan agama berbasis multikultural yang dianggap sesuai untuk kondisi praktis di masyarakat. ${ }^{34}$

\section{Metodologi Penelitian}

Penelitian ini bertujuan untuk mendiskripsikan secara umum tentang kreativitas guru SD/MI dalam mendesain pembelajaran PAI dan implikasinya terhadap pengembangan sikap toleransi siswa di MIN 1 Sila. Penelitian ini menggunakan pendekatan kualitatif dengan jenis penelitian studi kasus. Metode pengumpulan data dengan wawancara, observasi, dan

${ }^{33}$ Zulyadin, Penanaman Nilai-nilai Toleransi Beragama Pada Pembelajaran Pendidikan Agama Islam (PAI). Dalam Jurnal Pendidikan Al-Riwayah Vol. 10 No. 12018 UIN Mataram.

${ }^{34}$ Hadi Masruri, Pengembangan Model Pembelajaran Pendidikan Agama Islam (PAI) Berbasis Multikultural Dalam Meningkatkan Sikap Toleransi dan Kerukunan Beragama, (Malang, LP2M UIN Malang, 2016), hlm. 22. 
Jurnal Ilmiah "Kreatif" Vol. 18 No. 2, Juli 2020 "Jurnal Studi Pemikiran Pendidikan Agama Islam"

dokumentasi. ${ }^{35}$ Adapun sumber informan dalam penelitian ini adalah kepala sekolah, Wakasek Kurikulum dan guru mata pelajaran PAI. Adapun metode pengumpulan data dalam penelitian adalah melalui observasi, wawancara dan dokumentasi. Metode analisis data menggunakan teknik analisis deskriptif.

\section{Pembahasan}

\section{Kreativitas Guru Dalam Desain Pembelajaran PAI di MIN 1 Sila}

\section{Menciptakan Bahan Ajar Inovatif}

Dalam mewujudkan proses pembelajaran yang baik, Guru harus memiliki kemampuan dalam menciptakan sebuah konsep bahan ajar yang inovatif, menarik, menyenangkan bagi siswa dan kontekstual dengan pembelajaran di abad 21. Idham Khalid menjelaskan bahwa kemampuan guru dalam menciptakan bahan ajar yang inovatif merupakan salah satu kompetensi yang harus dimiliki oleh guru khususnya guru mata pelajaran PAI di MIN 1 Sila, hal ini sesuai dengan Undang-undang Guru Nomor 14 tahun 2005 Pasal 8 disebutkan bahwa "Guru wajib memiliki kualifikasi akademik, kompetensi, sertifikasi pendidik, sehat jasmani dan rohani, serta memiliki kemampuan untuk mewujudkan tujuan pendidikan nasional". ${ }^{36}$ Kompetensi guru sebagaimana dimaksud dalam undang-undang tersebut meliputi kompetensi pedagogis, kompetensi kepribadian, kompetensi sosial, dan kompetensi professional. Adapun kemampuan guru dalam menciptakan bahan ajar yang inovatif merupakan bagian dari kompetensi pedagogis.

Membuat dan menyusun bahan ajar yang inovatif sebenarnya adalah perkara yang mudah. Namun, selama ini di MIN 1 Sila dihadapkan dengan terbatasnya literatur atau referensi yang mengulas tentang tema-tema yang terdapat dalam buku ajar SD/MI, baik itu di tokoh buku maupun perpustakaan sekolah. Hal ini menjadikan guru di

\footnotetext{
${ }^{35}$ Jhon Creswell, Penelitian Kualitatif dan Desain Riset, Memilih Diantara Lima Pendekatan (Yogyakarta: Pustaka Pelajar, 2014), hlm. 11.

${ }^{36}$ Idham Khalid. 2019. Wawancara Dengan Kepala Sekolah MIN 1 Sila
} 
Jurnal Ilmiah "Kreatif" Vol. 18 No. 2, Juli 2020

"Jurnal Studi Pemikiran Pendidikan Agama Islam"

MIN 1 Sila sulit untuk mewujudkan tuntutan tersebut. Juwaid Umar dalam suatu kesempatan ketika diwawancara oleh penulis mengutarakan persoalan ini sebagaimana penjelasannya dibawah ini:

"Guru MIN 1 Sila telah berusaha semaksimal mungkin untuk menciptakan sebuah konsep pembelajaran yang inovatif, agar dalam proses pembelajaran siswa dapat mengerti dan memahami materi yang akan disampaikan. Akan tetapi guru di MIN 1 Sila dihadapkan dengan kurang atau minimnya sumber bacaan, referensi, buku yang sesuai dengan materi yang diajarkan, sehingga dalam proses pelaksanaanya tidak sesuai dengan diinginkan. Dengan kondisi seperti ini, maka guru diharuskan untuk memaksimalkan sumberdaya yang ada". 37

Persoalan ini merupakan sebuah fenomena yang sungguh menyedihkan dan sekaligus sangat memprihatinkan bagi pengembangan sekolah di MIN 1 Sila, salah satu tolak ukur ketercapaiannya sebuah pembelajaran yang baik adalah terciptanya konsep materi yang inovatif dan menyenenagkan bagi siswa yang didukung oleh sumberdaya buku referensi bacaan yang sesuai.

Dalam mendesain bahan ajar inovatif pada mata pelajaran PAI di MIN 1 Sila, guru harus memahami bahwa langkah pertama yang dilakukan dalam mendesain bahan ajar inovatif adalah sebagai berikut:

a. Menganalisis Kurikulum

Langkah pertama ini ditunjukan untuk menentukan kompetensi-kompetensi yang diharapkan mampu dikuasai oleh siswa. Minimal ada lima hal mesti dipelajari sebagai berikut: pertama, standar kompetensi, yakni kualifikasi kemampuan minimal siswa mulai dari pengetahuan, sikap dan keterampilan, kedua, kompetensi dasar, yakni kemampuan yang harus dimiliki oleh siswa pada mata pelajaran tertentu, misalnya pendidikan agama islam, ketiga, Indikator, yakni ketercapaian hasil belajar. Indikator adalah rumusan kompetensi yang spesifik, keempat, materi pokok, yakni sejumlah informasi utama berupa pengetahuan, keterampilan atau

\footnotetext{
${ }^{37}$ Juwaid Umar. 2019. Wawancara Dengan Guru Mata Pelajaran PAI MIN 1 Sila
} 
Jurnal Ilmiah "Kreatif" Vol. 18 No. 2, Juli 2020 "Jurnal Studi Pemikiran Pendidikan Agama Islam"

nilai yang disusun oleh guru sesuai dengan mata pelajaran dan tingkat kompetensi yang telah ditetapkan, dan kelima, pengalaman belajar, yakni aktivitas yang didesain oleh guru supaya dilakukan oleh siswa melalui kegiatan pembelajaran yang dilaksanakan di sekolah.

Dari lima poin penjelasan tentang langkah-langkah dalam mendesain bahan ajar inovatif diatas merupakan rangkaian kegiatan yang harus dilakukan oleh guru dalam menciptakan bahan ajar yang inovatif. Berdasarkan pengamatan dan data-data berupa dokumen yang didapatkan oleh peneliti di sekolah MIN 1 sila, maka dapat disimpulkan bahwa guru mata pelajaran PAI di MIN 1 Sila telah mampu menciptakan bahan ajar inovatif, ini bisa dilihat dari kemampuan guru dalam membuat Rencana Pelaksanaan Pembelajaran (RPP). Secara keseluruhan guru di MIN 1 Sila dan termasuk didalamnya adalah guru mata pelajaran PAI bisa membuat RPP sebagai rencana awal yang akan dilakukan oleh guru dalam proses pembelajaran. Pembuatan RPP merupakan salah satu intrumen dalam menilai kemampuan guru untuk menciptakan bahan ajar inovatif.

b. Menganalisis Sumber Belajar

Setelah menganalisis kurikulum, langkah selanjutnya adalah menganalisis sumber belajar. Adapun kriteria analisis terhadap sumber belajar dilakukan berdasarkan ketersediaan, kesesuaian, dan kemudahan dalam memanfaatkannya. Meskipun pada penjelasan sebelumnya peneliti mengutarakan tentang minimnya ketersediaan literature, buku referensi di MIN 1 Sila, namun pada pelaksanaannya guru dapat menyesuaikan dengan kondisi yang ada. Misalnya guru bisa menggunakan sumber belajar online, jurnal, artikel yang bisa di download di internet. Dan disekolah juga telah disediakan fasilitas internet secara gratis. Oleh karena itu, tidak ada alas an bagi guru untuk tidak membuat bahan ajar yang inovatif. 
Jurnal Ilmiah "Kreatif" Vol. 18 No. 2, Juli 2020

"Jurnal Studi Pemikiran Pendidikan Agama Islam"

c. Memilih dan Menentukan Bahan Ajar

Berkaitan dengan pemilihan bahan ajar, ada tiga prinsip yang harus dijadikan sebagai pedoman: pertama, Relevansi, yaitu bahan ajar yang dipilih harus ada relasi dengan pencapaian standar kompetensi maupun kompetensi dasar, kedua, prinsip konsistensi, yaitu bahan ajar yang dipilih memiliki nilai keajegan, antara kompetensi dasar dengan bahan ajar memiliki kesamaan dan keselarasan, ketiga, prinsip kecukupan, yaitu ketika memilih bahan ajar hendaknya dicari yang memadai untuk membantu siswa menguasai kompetensi dasar yang diajarkan.

\section{Menciptakan Proses Pembelajaran Menyenangkan}

Jika dilihat dari psikologi perkembangan peserta didik, maka siswa SD/MI masuk pada tahap perkembangan operasional konkrit. Pada tahap ini, anak sudah mulai berpikir secara logis terhadap kejadiankejadian konkrit. Pada tahap ini juga siswa mulai dapat menggambarkan secara menyeluruh ingatan, pengalaman, dan objek yang dialaminya, serta mampu beradaptasi dengan lingkungan sekitarnya. Dengan demikian guru mata palajaran pendidikan agama islam di MIN 1 sila harus mampu menciptakan proses pembelajaran dengan melihat dan memperhatikan karakter serta gaya belajar siswa.

Pembelajaran menyenangkan bagi siswa adalah rangkaian kegiatan pembelajaran yang melibatkan siswa secara aktif untuk mengkonstruksi pengetahuannya dengan cara mengintegrasikan ide dan pengalamannya dalam dunia nyata. Raodatul Janah, menjelaskan tentang konsep pembelajaran menyenangkan ini sebagaimana berikut:

"Pembelajaran dengan menyesuaikan fakta dan pengalaman yang dialami oleh siswa didunia nyata, yakni berdasarkan realitas kehidupan yang ada disekitarnya dapat menciptakan proses pembelajaran yang lebih bermakna, karena siswa cepat mengerti, dan siswa mempunyai kesempatan untuk berdiskusi 
Jurnal Ilmiah "Kreatif" Vol. 18 No. 2, Juli 2020 "Jurnal Studi Pemikiran Pendidikan Agama Islam"

dan saling bertukar pengalaman dan ilmu pengetahuan dengan temannya".

Selanjutnya beliau juga menyampaikan bahwa materi pembelajaran PAI menjadi lebih mudah untuk dipelajari dan dipahami oleh siswa, sebab materi PAI di SD/MI sangat bersentuhan langsung dengan kehidupan siswa sehari-hari. Misalnya, materi tentang Iman, Ibadah, Akhlak, dan hukum-hukum islam. Materi-materi tersebut tidak lagi hanya dijelaskan secara teoritis dan konseptual yakni dengan menyuruh siswa untuk menulis dan menghafal, akan tetapi lebih kepada wilayah faktual.

Untuk mendukung tingkat ketercapaian guru dalam mendesain pembelajaran menyenangkan, maka peneliti akan menjelaskan beberapa poin penting tentang sistematika penyusunan pembelajaran menyenangkan mulai dari pemilihan strategi, metode dan media pembelajaran yang diterapkan pada pembelajaran PAI di MIN 1 Sila sebagamana berikut:

a. Menyusun materi yang menyenangkan

Pada poin ini penulis tidak akan menjelaskan secara rinci dan detail terkait dengan cara guru MIN 1 Sila dalam menyusun materi yang menyenangkan, karena pada penjelasan sebelumnya telah dibahas terkait dengan guru menciptakan bahan ajar inovatif. Pada umunya disini dapat dijelaskan bahwa materi yang menyenangkan adalah materi yang disampaikan kepada siswa tentang fakta-fakta konkrit dalam dunia nyata yang dihubungkan dengan materi-materi berdasarkan tema dalam buku ajar siswa.

b. Strategi pembelajaran menyenangkan

Salah satu strategi pembelajaran menyenangkan yang diterapkan oleh guru dalam pembelajaran PAI di MIN 1 Sila adalah strategi kontekstual learnig. Dalam penerapannya strategi ini sangat sesuai dengan model pembelajaran di abad 21 dengan menggunakan

${ }^{38}$ Raodatul Janah. 2019. Wawancara Dengan Guru Mata Pelajaran PAI MIN 1 
Jurnal Ilmiah "Kreatif" Vol. 18 No. 2, Juli 2020

"Jurnal Studi Pemikiran Pendidikan Agama Islam"

pendekatan ilmiah. Selain strategis tersebut ada banyak strategi yang bisa implmentasikan oleh guru demi terwujudnya tujuan pembelajaran yang diharapkan.

c. Metode pembelajaran menyenangkan

Metode yang diterapkan oleh guru dalam proses pembelajaran cukup bervariasi dan tidak monoton. Hal ini dikarenakan agar materi yang disampaikan oleh tidak terkesan kaku dan tidak terorganisir dengan baik.

d. Media pembelajaran menyenangkan

Adapun media pembelajaran yang digunakan oleh guru untuk menyampaikan materi pembelajaran PAI di MIN Sila adalah media gambar, video, film dll. Media pembelajaran digunakan untuk mempermudah guru dalam menyampaikan informasi-informasi tentang ilmu pengetahuan tentang pendidikan agama islam.

Dari uraian diatas, dapat disimpulkan bahwa guru mata pelajaran pendidikan agama islam MIN 1 Sila menerapkan sebuah konsep pembelajaran berdasarkan kurikulum 2013, yakni menciptakan pembelajaran PAI yang menyenangkan bagi siswa dengan melibatkan siswa sebagai subyek dan obyek pembelajaran secara bersamaan dan dikembangkan dengan model pembelajaran kontekstual di abad 21.

\section{Kemampuan Menjelaskan Materi Dengan Baik}

Realitas menjelaskan adanya banyak guru agama islam yang belum bisa menulis Al-Qur'an secara baiik dan benar di papan tulis pada saat menyampaikan materi agama islam, bahkan yang lebih parah adalah masih ada guru pendidikan agama islam yang belum bisa membaca AlQur'an dengan baik yakni berdasarkan pengucapan huruf dan tajwid yang benar. Masalah ini akan berdampak negatif terhadap transformasi pengetahuan kepada siswa pada saat proses pembelajaran di sekolah.

Secara akademik rata-rata guru mata pelajaran pendidikan agama islam di MIN Sila berasal dari lulusan jurusan S1 Pendidikan Agama Islam di peruguruan tinggi ternama di Indonesia, misalnya UIN, 
Jurnal Ilmiah "Kreatif" Vol. 18 No. 2, Juli 2020

"Jurnal Studi Pemikiran Pendidikan Agama Islam"

Universitas Muhammadiyah dan Sekolah Tinggi Islam, baik yang ada di Bima maupun di berbagai kota di Indonesia, misalnya Kota Makasar, Mataram, Malang dan Yogyakarta. Hal ini seperti yang disampaikan oleh kepala MIN 1 Sila sebagai berikut:

"Guru MIN 1 Sila yang mengajar mata pelajaran pendidikan agama islam rata-rata secara keseluruhan dari jurusan S1 Pendidikan Agama Islam. Mereka dari berbagai alumni kampuskampus ternama di Indonesia, seperti UMI Makasar, Unismu Makasar, IAIM Bima, UIN Mataram, UIN Malang dll. Dengan adanya guru-guru tersebut, maka proses pembelajaran selama ini berjalan dengan baik dan sesuai dengan tingkat profesionalitas sebagaimana yang teratur dalam system pendidikan kita di Indonesia".

Berdasarkan penjelasan diatas menunjukan secara kualifikasi pendidikan guru pendidikan agama islam di MIN 1 Sila telah memiliki kompetensi untuk mengajar materi-materi agama islam di SD/MI. Hal ini terbukti dengan hasil pengamatan yang dilakukan oleh peneliti, bahwa guru PAI di MIN 1 sila mampu memaparkan dan menjelaskan materi agama islam dengan baik dan benar, serta rata-rata baca AlQur'annya bagus dan bisa menulisnya papan tulis.

\section{Penanaman Sikap Toleransi Siswa di MIN 1 Sila}

Pembelajaran era abad 21 menggunakan paradigma pembelajaran berbasis nilai, sehingga dalam pelaksanaan pembelajarannya guru tidak hanya memberi tahu informasi-informasi yang dapat menunjang kemampuan kognitif siswa, tetapi guru juga harus menumbuhkan aspek sikap dan keterampilan. Salah satu aspek sikap yang harus ditanamkan oleh guru pada siswa adalah sikap toleransi. MIN 1 Sila sebagai salah satu institusi pendidikan yang berada pada naungan Kementrian Agama harus merespon secara cepat program yang dicanangkan oleh Menteri Agama RI yakni tentang moderasi islam. Moderasi islam adalah sebuah konsep pehaman Islam yang anti akan ekstrimisme, radikalisme, intoleransi dan lain sebagainya.

\footnotetext{
${ }^{39}$ Idham Khalid. 2019. Wawancara Dengan Kepala Sekolah MIN 1 Sila
} 
Jurnal Ilmiah "Kreatif" Vol. 18 No. 2, Juli 2020 "Jurnal Studi Pemikiran Pendidikan Agama Islam"

Dalam konteks pembelajaran PAI, guru mata pelajaran PAI di MIN 1 Sila harus bisa mendesain materi pembelajaran agama islam dengan menanamkan nilai-nilai toleransi yang bersumber pada Al-Qur'an dan Hadits. Ibu Raodatul Jannah menyebutkan bahwa, nilai-nilai toleransi yang ditanamkan pada mata pelajaran PAI di MIN 1 Sila tidak hanya dimaknai dengan sikap toleransi dalam beragama, akan tetapi seluruh aspek kehidupan yang dihadapi oleh siswa. Misalnya perbedaan status sosial, perbedaan fisik, perbedaan dialek, dan perbedaan suku,. ${ }^{40}$ Mewujudkan sikap toleransi dalam pembelajaran agama Islam merupakan bagian dari pilar pendidikan nasional yakni menekankan kesadaran tentang pentingnya hidup bersama atau mengerti keadaaan orang lain.

Penggunaan sikap toleransi akan memunculkan adanya kedamaian dan kerukunan. Keadaan damai diartikan sebagai tidak adanya perang atau kerusuhan, padahal saat ini memang tidak terjadi konflik secara langsung namun yang terjadi terdapat berbagai permasalahan secara internal dan latent pada keadaan yang masing-masing berusaha menjaga dan menahan diri, sehingga sikap toleransi perlu tetap dijaga melalui karakteristik kepribadian yang dapat memahami kemajemukan secara positif. Bisa dipastikan, toleransi mengandung unsur ketenangan dan kedamaian yang terbangun atas prinsip keterbukaan dan penghargaan yang tinggi yang mengikat pada wujud nilai persaudaraan dan kemanusiaan.

Berdasarkan hasil pengamatan peneliti dilapangan, sikap keterbukaan dalam memahami perbedaan masih menjadi pekerjaan tersulit yang dihadapi oleh guru di MIN 1 Sila. Juwaid Umar mengatakan, jika dilihat dari keseharian siswa di MIN 1 Sila, masih ditemukan beberapa siswa yang tidak mau menghargai temannya, kami selaku guru khususnya guru PAI terus menyampaikan kepada siswa tentang pentingnya hidup bersama, saling menghargai, menjunjung tinggi nilai-nilai persaudaraan serta sikap toleransi. ${ }^{41}$

\footnotetext{
${ }^{40}$ Raodatul Jannah, Wawancara Dengan Guru Mata Pelajaran PAI MIN 1 Sila

${ }^{41}$ Juwaid Umar. Wawancara Dengan Guru Mata Pelajaran PAI MIN 1 Sila.
} 
Jurnal Ilmiah "Kreatif" Vol. 18 No. 2, Juli 2020

"Jurnal Studi Pemikiran Pendidikan Agama Islam"

Meskipun pada kenyataannya masih ditemukan siswa yang memiliki sikap tidak terbuka dalam perbedaan. Namun upaya guru di MIN 1 Sila sudah menunjukan adanya tingkat ketercapaian dalam penanaman nilai-nilai sikap toleransi. Hal ini terbukti dengan masifnya pergerakan yang dilakukan oleh guru dalam membimbing dan membina siswa sesuai dengan konsep islam yang rahmatan lilalamin.

Dalam pembelajaran PAI, penanaman sikap toleransi adalah salah satu aspek yang sangat ditekankan. Ajaran islam yang dipelajari pada mata pelajaran pendidikan agama islam tidak hanya dipahami secara tekstual normatif, dalam artian doktrin-doktrin yang diajarakan dalam Al-Qur'an harus mampu dipahami secara terbuka dan tidak diskriminatif. Proses perencanaan, pelaksanaan, dan evaluasi pada mata pelajaran PAI harus berorientasi pada pengembangan keterampilan pengetahuan, sikap dan keterampilan. Sehingga sikap toleransi bukanlah sesuatu yang hadir secara spontanitas, tetapi merupakan desain guru PAI dalam pembelajaran. Ibu Raodatul Jannah menjelaskan bahwa pada saat penyusunan RPP, pembuatan bahan ajar serta penyampaian materi dalam pembelajaran tetap menanamkan sikap toleransi. ${ }^{42}$ Berdasarkan penjelasan tersebut, dalam implementasinya pembelajaran PAI di MIN 1 Kota Bima tetap menekankan pada aspek penanaman nilai-nilai sikap toleransi.

\section{Penutup}

Dalam mewujudkan proses pembelajaran yang baik, Guru harus memiliki kemampuan dalam menciptakan sebuah konsep bahan ajar yang inovatif, menarik, menyenangkan bagi siswa dan kontekstual dengan pembelajaran di abad 21. Selain itu, guru juga harus mampu menciptakan proses pembelajaran yang menyenangkan sesuai dengan tingkat perkembangan pengetahuan peserta didik. Dalam pembelajaran PAI, penanaman sikap toleransi adalah salah satu aspek yang sangat ditekankan. Ajaran islam yang dipelajari pada mata pelajaran pendidikan agama islam

\footnotetext{
${ }^{42}$ Raodatul Jannah. Wawancara Dengan Guru Mata Pelajaran PAI MIN 1 Sila.
} 
Jurnal Ilmiah "Kreatif" Vol. 18 No. 2, Juli 2020

"Iurnal Studi Pemikiran Pendidikan Agama Islam"

tidak hanya dipahami secara tekstual normatif, dalam artian doktrin-doktrin yang diajarakan dalam Al-Qur'an harus mampu dipahami secara terbuka dan tidak diskriminatif. Proses perencanaan, pelaksanaan, dan evaluasi pada mata pelajaran PAI harus berorientasi pada pengembangan keterampilan pengetahuan, sikap dan keterampilan. Sehingga sikap toleransi bukanlah sesuatu yang hadir secara spontanitas, tetapi merupakan desain guru PAI dalam pembelajaran.

\section{DAFTAR PUSTAKA}

Abdul Rachman Shaleh. Pendidikan Agama dan Keagamaan: Visi, Misi dan Aksi. Jakarta, Gemawindu Pancaperkasa, 2000.

Ahmad Munjin dan Lilik Nur Kholidah. Metode dan Tekhnik Pembelajaran Pendidikan Agama Islam. Bandung, Rafida Aditama, 2009.

Andi Prastowo. Pembelajaran Konstruktivistik-Saintific Untuk Pendidikan Agama di Sekolah/Madrasah. Jakarta, Raja Grafindo Persada, 2015.

Amen Haedari. Sinopsis Kajian Pendidikan Agama dan Keagamaan 20062009. Jakarta: Puslitbang Pendidikan Agama dan Keagamaan Badang Litbang dan Diklat Kementrian Agama RI, 2010.

Choirul Mahfud. Pendidikan Multikultural. Yogyakarta, Pustaka Pelajar, 2011.

Depdiknas. 2003. UU No. 2 Tentang Sistem Pendidikan Nasional (SISDIKNAS). Jakarta, Depdiknas.

Guntur Talajan. Menumbuhkan Kreativitas dan Prestasi Guru. Yogyakarta, Laksbang Pressindo, 2012.

Hadi Masruri. Pengembangan Model Pembelajaran Pendidikan Agama Islam (PAI) Berbasis Multikultural Dalam Meningkatkan Sikap Toleransi dan Kerukunan Beragama, (Malang, LP2M UIN Malang, 2016.

Ibnu Hadjar. Pendekatan Keberagamaan Dalam Pemilihan Metode Pengajaran Pendidikan Agama Islam. Yogyakarta, Pustaka Pelajar, 2004

Idham Khalid. 2019. Wawancara Dengan Kepala Sekolah MIN 1 Sila, 2019.

Imam Tholkhah. Urgensi Pengembangan Pengembangan Pendidikan Agama Islam di Sekolah. Jakarta, Rajagrafindo Persada, 2009.

Imron Rossidy. Pendidikan Berparadigma Inklusif. Malang, UIN Malang Press, 2009.

Juwaid Umar. Wawancara Dengan Guru Mata Pelajaran PAI MIN 1 Sila, 2019

Kamus Besar Bahasa Indonesia. Jakarta, Balai Pustaka, 1997.

Marwan Saridjo. Bunga Rampai Pendidikan Agama Islam. Jakarta, Amisso, 1996. 
Jurnal Ilmiah "Kreatif" Vol. 18 No. 2, Juli 2020

"Iurnal Studi Pemikiran Pendidikan Agama Islam"

Marwan Saridjo. Pendidikan Islam Dari Masa ke Mas: Tinjauan Kebijakan Publik Terhadap Pendidikan Islam di Indonesia. Bogor, Ngali Aksara dan Al-Manar Press, 2011.

Moch. Uzer Usman. Menjadi Guru Profesional. Bandung, PT Remaja Rosdakarya, 2011.

Muhaimin, dkk. Paradigma Pendidikan Islam: Upaya Mengefektifkan Pendidikan Agama Islam di Sekolah. Bandung, Remaja Rosdakarya.

Nana Syaodih Sukmadinata. 1995. Pengembangan Kurikulum. Bandung, Remaja Rosdakarya, 2004.

Ngainun Naim. Menjadi Guru Inspiratif Memberdayakan dan Mengubah Jalan Hidup Siswa. Yogyakarta, Pustaka Pelajar, 2009.

Nurholish Madjid. Cendikiawan \& Religiusitas Masyarakat. Jakarta, Paramadina, 1999.

Pusat Kurikulum Depdiknas. Standar Kompetensi Mata Pelajaran Agama Islam Sekolah Dasar dan Madrasah Ibtidaiyah. Jakarta, Depdiknas, 2004.

Raodatul Janah. Wawancara Dengan Guru Mata Pelajaran PAI MIN 1 Sila. 2019.

Rusman. Model-model Pembelajara: Mengembangkan Profesionalisme Guru. Jakarta, Rajawali Pers, 2010.

Siti Aesijah dan Eko Raharjo. Kreativitas Guru Dalam Pembelajaran Musik Di Taman Kanak-Kanak (TK) Kemala Bhayangakari 62 Boyolali. Dalam Jurnal Seni Musik No. 6 Vol. 2 Universitas Negeri Semarang, 2017.

Syafiq A. Mughni. Pendidikan Berbasis Multikulturalisme. Sidorjo, Universitas Muhammadiyah Sidoarjo, 2005.

Tim Penyusun Pusat Bahasa Depdiknas. Kamus Besar Bahasa Indonesia, Edisi Keempat. Jakarta, Gramedia Pustaka Utama, 2008.

Trianto. Desain Pengembangan Pembelajaran Tematik Bagi Anak Usia Dini TK/RA dan Anak Usia Awal SD/MI. Jakarta, Kencana Prenada Media Group, 2013.

Zulyadin. Penanaman Nilai-nilai Toleransi Beragama Pada Pembelajaran Pendidikan Agama Islam (PAI). Dalam Jurnal Pendidikan AlRiwayah Vol. 10 No. 1 UIN Mataram, 2018. 